\section{Når verden vil bedras}

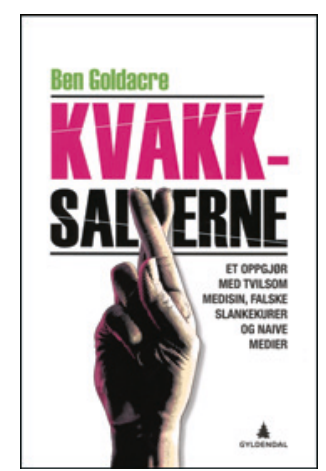

Ben Goldacre

\section{Kvakksalverne}

Et oppgjør med tvilsom medisin, falske slankekurer og naive medier. 374 s, tab, ill. Oslo: Gyldendal, 2012. Pris NOK 399 ISBN 978-82-05-42287-2
Bad Science. Quacks, Hacks, and Big Pharma Flacks kom ut i England i 2008 og er nå oversatt til norsk. Den engelske utgaven er tidligere anmeldt i Tidsskriftet (1).

Den 38 år gamle forfatteren er psykiater og har i flere år vært ansvarlig for spalten «Bad Science» i The Guardian. Boken er beregnet på den opplyste allmennheten, og hans håp er at opplysning om hvordan vitenskapen arbeider, skal kunne vaksinere folk mot kvakksalvermedisinen og medienes fordummende medisinske «nyheter», enten det gjelder slankekurer eller kosttilskudd.

Hvordan vet vi at en intervensjon, en behandling, virker? Enten det gjelder ansiktskrem, såkalte avgiftningskurer eller medisin mot hjerteinfarkt, er teknikken for å teste en intervensjon den samme. Systematiske undersøkelser med randomisering og dobbeltblinding, der verken pasient eller lege vet hvem som har fått antatt virksomt medikament, og hvem som har fått placebo, er nødvendig. Tilfeldige kasuistikker er ikke tilstrekkelig.

Før 1935 hadde vi ikke mange effektive behandlinger. Vi hadde insulin, lever mot jernmangelanemi og morfin, men så fikk vi en periode frem til 1975 med en rekke undersøkelser og behandlinger som revolusjonerte medisinen, som antibiotika og en rekke andre medikamenter, dialyse, transplantasjon og hjertekirurgi.

Når homeopati og andre uvitenskapelige metoder virker, er det naturligvis fordi pasienten tror på behandlingen og fordi noen tar ham på alvor, lytter, forklarer og $\mathrm{i}$ beste fall gir håp. Selve den homeopatiske medisinen har ingen virkning. Homeopatien ble utviklet av en tysk lege, Samuel Hahnemann, på slutten av 1700tallet, i en tid da den vanlige medisinen hadde lite å fare med. I den ordinære medisinen er imidlertid årelating og andre uvirksomme metoder etter hvert blitt avskaffet.

Forfatteren gir mange eksempler på virkningen av placebo. En amerikansk misjonær beskrev hvordan han på midten av 1800-tallet opererte en kinesisk pasient uten bedøvelse. Etter operasjonen hoppet pasienten ned på gulvet, bukket og gikk ut av rommet som om ingenting hadde hendt. I 1950-årene trodde noen kirurger og indremedisinere at man kunne få blodkar i hjertet til å vokse ut igjen hvis man underbandt en arterie i brystveggen som ikke var særlig viktig, men som var en forgreining fra hjertes viktigste arterier. Pasienter med angina pectoris forklarte etter operasjonen at de nå kunne gå i trapper som andre mennesker, både smerten og andpustenheten var borte, altså en vellykket operasjon. Noen skeptiske leger utførte så i 1959 en narreoperasjon på en tilsvarende gruppe pasienter med angina pectoris. De gjorde et overflatisk snitt i brysthuden, uten at pasienten var klar over det. Resultatet av denne «sham»- operasjo- nen var like godt som etter den ordinære operasjonen. Flere av pasientene kunne anstrenge seg som i gamle dager uten brystsmerter, og andre fortalte at de hadde sluttet med nitroglyserin. Virkningen berodde åpenbart på placeboeffekten. Tro kan flytte fjell.

Forfatteren går relativt grundig inn på kostholdspropagandaen og angriper særlig Gillian McKeith, multimillionæren og pillegründeren som har sitt eget sortiment med matvarer, mystisk pulver og rare piller. I beste sendetid på engelsk TV underviser hun om kosthold, men ifølge forfatteren serverer hun det rene visvas. «Kostholdsdoktoren» har en tvilsom doktorgrad i ernæringslære, men presenteres som lege med hvit frakk, omgitt av reagensrør og blodprøver. For kanal 4 er hun en vitenskapelig autoritet på ernæring. Også her i landet hører vi om diverse kosttilskudd: Glukosamin kan bedre leddbetennelse, antioksidanter kan forebygge kreft og hjertesykdom, og fiskeolje med omega-3 gir økt intelligens.

En stor randomisert undersøkelse fra Finland, publisert i New England Journal of Medicine i 1994, viste at de personene som fikk betakaroten eller vitamin E eller begge deler, hadde flere dødsfall av både hjerteinfarkt og lungekreft enn normalgruppen. I en annen undersøkelse publisert i samme tidsskrift to år senere hadde halvparten fått betakaroten og vitamin $\mathrm{A}$, mens kontrollgruppen hadde fått placebo. Personer som fikk antioksidanttabletter hadde langt større risiko for å dø av lungekreft og større risiko for å dø i det hele tatt enn personer som tok placebopiller. Cochrane Collaboration har siden bekreftet dette ved metaanalyser.

Hvorfor ikke høre på Statens ernæringsråd og Kaare Norum med sine enkle og gode råd? Spis mye frukt og grønnsaker, mosjoner regelmessig, unngå fedme, ikke drikk for mye, og ikke røyk! Gjør man dette, kan man holde seg borte fra kosttilskudd og slankedietter.

Boken er vel verdt et studium. Den er både underholdende og opplysende og inneholder langt mer enn jeg har hatt anledning til å kommentere. Omtalen av placebo kunne nok ha vært bedre, og en del forhold er spesielle for Storbritannia, men alt $i$ alt er dette et glimrende stykke arbeid.

\section{Einar Kringlen}

Psykiatrisk institutt, Vinderen

Universitetet i Oslo

\footnotetext{
Litteratur

1. Slørdal L. Hva slags fag har du tilhold i? Anmeldelse av: Goldacre B. Bad science. Tidsskr Nor Legeforen 2009; 129: 1378.
} 